\title{
PENGARUH KECERDASAN EMOSIONAL DAN KEMANDIRIAN BELAJAR TERHADAP KEMAMPUAN BERPIKIR KREATIF SISWA KELAS VIII SMP NEGERI 2 KOTA JAMBI
}

\author{
Sarifah Yeni ${ }^{1}$, Buyung $^{2}$, Sri Dewi ${ }^{3}$ \\ Mahasiswa Pendidikan Matematika, FKIP, Universitas Batanghari, Jambi ${ }^{1}$ \\ Dosen Pendidikan Matematika, FKIP Universitas Batanghari, Jambi ${ }^{2,3}$ \\ Email: -
}

\begin{abstract}
ABSTRAK
Pada proses pendidikan mampu mempengaruhi baik kecerdasan intelektual maupun emosional. Kecerdasan emosional merupakan kemampuan siswa dalam mengendaikan emosi dari dalam diri sendiri sehingga dapat menyelesaikan tugas yang dibebankan dengan baik. Siswa yang mempunyai kecerdasan emosional yang kuat akan di ikuti dengan munculnya kemandirian belajar dan berpikir kreatif siswa. Jenis penelitian adalah kuantitatif, yaitu penelitian yang digunakan untuk meneliti populasi dan sampel tertentu populasi yang diambil adalah seluruh kelas VIII SMPN 2 Kota Jambi dengan menggunakan teknik random sampling yaitu teknik pengambilan anggota sampel secara acak. Sampel dalam penelitian ini adalah siswa kelas VIII SMPN 2 Kota Jambi, sebanyak 70 siswa dari 2 kelas. Teknik pengumpulan data mengunakan kuesioner/angket untuk kecerdasan emosional dan kemandirian belajar, tes untuk kemampuan berpikir kreatif. Teknik analisis data menggunakan analisis regresi linier berganda. Hasil dari penelitian ini menunjukkan bahwa : (1) terdapat pengaruh kecerdasan emosional terhadap kemampuan berpikir kreatif dengan nilai koefisien korelasi sebesar 0,07 sehingga termasuk dalam kategori lemah; (2) tidak terdapat pengaruh kemandirian belajar terhadap kemampuan berpikir kreatif dengan nilai koefisien korelasi sebesar -0,08 sehingga termasuk dalam kategori sangat lemah; (3) terdapat pengaruh kecerdasan emosional dan kemandirian belajar terhadap kemampuan berpikir kreatif dengan nilai koefisien korelasi sebesar 0,15 sehingga termasuk dalam kategori lemah. Kecerdasan emosional dan kemandirian belajar berpengaruh sebanyak 2,8\% terhadap kemampuan berpikir kreatif siswa kelas VIII SMPN 2 Kota Jambi sedangkan selebihnya 97,2\% dipengaruhi oleh variabel lain yang tidak masuk dalam penelitian ini.
\end{abstract}

Kata kunci : Kecerdasan Emosional, Kemandirian Belajar, Kemampuan Berpikir Kreatif

\begin{abstract}
In the educational process is able to influence both intellectual and emotional intelligence. Emotional intelligence is the ability of students in controlling emotions from within themselves so that they can complete the tasks that are charged properly. Students who have strong emotional intelligence will be followed by the emergence of students' independent learning and creative thinking. This research is quantitative, namely research used to examine populations and certain samples. The population taken was the entire class VIII of SMPN 2 Jambi City by using a random sampling technique that is a random sample collection technique. The sample in this study were students of class VIII SMPN 2 Kota Jambi, as many as 70 students from 2 classes. Data collection techniques using a questionnaire / questionnaire for emotional intelligence and learning independence, tests for creative thinking skills. Data analysis techniques used multiple linear regression analysis. The results of this study indicate that: (1) there is an influence of emotional intelligence on the ability to think creatively with a correlation coefficient of 0.07 so that it is included in the weak category; (2) there is no influence of learning independence on the ability to think creatively with a correlation coefficient of -0.08 so that it is included in the very weak category; (3) there is an influence of emotional intelligence and learning independence on the ability to think creatively with a correlation coefficient of 0.15 so that it is included in the weak category. Emotional intelligence and learning independence influenced $2.8 \%$ of the creative thinking abilities of Grade VIII students of SMPN 2 Jambi City while the rest $97.2 \%$ were influenced by other variables not included in this study.
\end{abstract}

Keywords : Emotional Intelligence, Learning Independence, Creative Thinking Ability 


\section{$\pi$ (Phi)}

\section{PENDAHULUAN}

Pendidikan merupakan salah satu faktor yang mempengaruhi terbentuknya karakter suatu bangsa. Dimana melalui pendidikan dapat meningkatkan kualitas sumber daya manusia yang ada. Pendidikan adalah suatu usaha atau kegiatan yang dijalankan dengan sengaja, teratur dan berencana dengan maksud mengubah atau mengembangkan perilaku yang diinginkan. Dalam pendidikan ada dua komponen yang diterapkan yaitu belajar dan mengajar. Salah satu wadah yang menampung kegiatan ini adalah sekolah yaitu suatu lembaga formal dengan tujuan pencapaian pendidikan. Belajar merupakan kegiatan penting setiap orang, termasuk di dalamnya belajar bagaimana seharusnya belajar.

Belajar merupakan aktivitas yang dilakukan untuk mendapatkan pengetahuan, keterampilan dan kecakapan. Aktivitas belajar akan menghasilkan perubahan dalam diri seseorang. Tujuan akhirnya adalah seseeorang mampu menyesuaikan diri dengan lingkungan dan mampu mewujudkan apa yang di citacitakan.

Siswa melakukan aktivitas belajar yang utama di sekolah sebagai pusat pendidikan berlangsung secara formal. Selain di sekolah, belajar juga dapat dilakukan siswa di luar sekolah baik di rumah maupun di dalam lingkungan masyarakat. Proses belajar yang dilakukan siswa di sekolah maupun di luar sekolah secara alami meningkatkan kepercayaan diri dan kemandirian siswa dimana hal ini mempengaruhi pertumbuhan kecerdasan baik intelektual maupun emosional.

Berdasarkan observasi yang dilakukan melalui wawancara dengan salah satu guru matematika kelas VIII di SMPN 2 Kota Jambi menerangkan tingkat kecerdasan emosional dan kemandirian belajar siswa masih harus ditingkatkan. Dapat dilihat dengan cara ketika siswa mengerjakan soal pada saat guru memberi latihan. Sehingga setiap kelas memiliki tingkat kemampuan berpikir kreatif yang berbeda, dilihat dari ketidakmerataan kemampuan beberapa kelas yang rendah dan beberapa kelas yang tinggi.

Menurut Lestari dan Yudhanegara (2015) Kemampuan berpikir kreatif adalah kemampuan untuk menghasilkan ide atau gagasan yang baru dalam menghasilkan suatu cara dalam menyelesaikan masalah, bahkan menghasilkan cara yang baru sebagai solusi alternatif.

Indikator kemampuan berpikir kreatif matematis sebagai berikut (Lestari dan Yudhanegara, 2015) :

1. Kelancaran (fluency)

2. Keluwesan (flexibility)

3. Keaslian (originality)

4. Elaborasi (elaboration)

Menurut Iskandar (2009) kecerdasan emosional adalah mencakup kemampuan untuk membedakan dan menanggapi dengan tepat suasana hati, temperamen, motivasi, dan hasrat antar-pribadi ini lebih menekankan pada aspek kognisi atau pemahaman. Sementara faktor emosi atau perasaan kurang diperhatikan. Padahal faktor emosi ini sangat penting dan memberikan suatu warna yang kaya dalam kecerdasan antar-pribadi ini. Menurut lestari dan yudhanegara (2015) kecerdasan emosional adalah kemampuan seseorang mengatur kehidupan emosinya dengan inteligensi, menjaga keselarasan emosi dan pengungkapannya melalui keterampilan kesadaran diri, pengendalian diri, motivasi diri, empati dan keterampilan sosial.

Goleman menjelaskan pendapat Salovey (Uno, 2010) yang menempatkan kecerdasan pribadi Gardner sebagai dasar dalam mendefinisikan kecerdasan emosional yang dicetuskannya. Dalam hal ini, indikator kecerdasan emosional, yaitu sebagai berikut.

1. Mengenali emosi diri

2. Mengelola emosi

3. Memotivasi diri sendiri

4. Mengenali emosi orang lain 


\section{$\pi$ (Phi)}

5. Membina hubungan

Kemandirian belajar diartikan sebagai belajar yang berbasis arah diri sendiri yang berfokus pada proses mengendalikan pembelajaran mereka sendiri. Kemandirian belajar akan terwujud apabila siswa aktif mengontrol sendiri segala sesuatu yang dikerjakan, mengevaluasi dan selanjutnya merencanakan sesuatu yang lebih dalam pembelajaran yang dilalui dan siswa juga mau aktif dalam proses pembelajaran (Danim dan Kahiril, 2010).

Adapun indikator kemandirian belajar Menurut Mujiman (2007) adalah :

1. Kegiatan belajar aktif

2. Motif untuk menguasai suatu kompetensi

3. Inisiatif

4. Kebebasan

Pentingnya kajian ini sehingga dilakukan penelitian dengan judul Pengaruh Kecerdasan Emosional Dan Kemandirian Belajar Terhadap Kemampuan Berpikir Kreatif Siswa kelas VIII SMP Negeri 2 Kota Jambi. Adapun tujuan dari penelitian ini adalah untuk melihat pengaruh kecerdasan emosional dan kemandirian belajar terhadap kemampuan berpikir kreatif siswa kelas VIII SMP Negeri 2 Kota Jambi.

\section{METODE PENELITIAN}

Jenis penelitian yang dilakukan dalam penelitian ini adalah kuantitatif. Penelitian kuantitatif dapat diartikan sebagai metode penelitian yang berlandaskan pada filsafat positivisme, digunakan untuk meneliti pada populasi atau sampel tertentu, teknik pengambilan sampel pada umumnya dilakukan secara random, pengumpulan data menggunakan instrumen penelitian, analisis data bersifat kuantitatif/statistik dengan tujuan untuk menguji hipotesis yang telah ditetapkan (Sugiyono, 2018).

Dalam penelitian ini yang akan dijadikan populasi adalah seluruh siswa kelas VIII SMP Negeri 2 Kota Jambi

sebanyak 217 siswa yang terbagi menjadi 6 kelas. Pengambilan sampel tersebut dengan random sampling dengan dipilih 2 kelas. Dan kelas yang terambil yaitu pertama VIII E dan kedua VIII F, dengan jumlah sampel sebanyak 70 siswa.

Teknik pengumpulan data dalam penelitian ini adalah kuesioner dan teknik tes. Data yang dianalisis adalah skor hasil dari kuesioner dan tes. Metode statistik yang digunakan adalah uji kesamaan ratarata dengan uji regresi linear berganda dan korelasi linear berganda untuk menguji hipotesis dalam penelitian ini. Sebelum dianalisis dilakukan terlebih dahulu uji normalitas dan uji homogenitas.

\section{HASIL DAN PEMBAHASAN Deskripsi Data}

Adapun pengolahan datanya secara manual dengan bantuan kalkulator dan microsoft excel.

Tabel 1. Statistik Angket Kecerdasan Emosional

\begin{tabular}{cc}
\hline Statistik & $\begin{array}{c}\text { Angket Kecerdasan } \\
\text { Emosional }\end{array}$ \\
\hline$\Sigma$ & 6717 \\
Min & 82 \\
Max & 110 \\
Mean & 95,95 \\
Simpangan Baku & 6,92 \\
\hline
\end{tabular}

Berdasarkan tabel diperoleh hasil, bahwa nilai keseluruhan dari kelas sampe pada Angket kecerdasan emosional ialah 6717 , nilai terendah yang diperoleh sampel ialah 82, sedangkan nilai tertinggi ialah 110. Hal ini menunjukkan, bahwa rata-rata yang dimiliki oleh sampel pada angket kecerdasan emosional sebesar 95,95.

Tabel 2. Statistik Angket Kemandirian Belajar

\begin{tabular}{cc} 
Statistik & $\begin{array}{c}\text { Angket Kemandirian } \\
\text { Belajar }\end{array}$ \\
\hline$\Sigma$ & 4479 \\
Min & 51 \\
Max & 76 \\
Mean & 63,98 \\
Simpangan Baku & 5,58 \\
\hline
\end{tabular}

Berdasarkan tabel diperoleh hasil, bahwa nilai keseluruhan dari kelas sampe pada Angket kemandirian belajar ialah 4479 , nilai terendah yang diperoleh sampel 


\section{$\pi$ (Phi)}

ialah 51, sedangkan nilai tertinggi ialah 76. Hal ini menunjukkan, bahwa rata-rata yang dimiliki oleh sampel pada angket kecerdasan emosional sebesar 63,98.

Tabel 3. Statistik Tes Kemampuan Berpikir Kreatif

\begin{tabular}{cc}
\hline Statistik & $\begin{array}{c}\text { Tes Kemampuan } \\
\text { Berpikir Kreatif }\end{array}$ \\
\hline$\Sigma$ & 6027 \\
Min & 45 \\
Max & 100 \\
Mean & 86,1 \\
Simpangan Baku & 12,37 \\
\hline Berdasarkan tabel diperoleh hasil,
\end{tabular}

bahwa nilai keseluruhan dari kelas sampe pada tes kemampuan berpikir kreatif siswa ialah 6027, nilai terendah yang diperoleh sampel ialah 45, sedangkan nilai tertinggi ialah 100. Hal ini menunjukkan, bahwa rata-rata yang dimiliki oleh sampel pada angket kecerdasan emosional sebesar 86,1.

\section{Hasil Pengujian Hipotesis}

Analisis ini untuk mengetahui apakah terdapat pengaruh kecerdasan emosional dan kemandirian belajar terhadap kemampuan berpikir kreatif siswa. Untuk pengujiannya harus memenuhi dua syarat yaitu uji normalitas dan uji homogenitas.

Tabel 4. Uji Normalitas Angket Dan Tes

\begin{tabular}{ccccc}
\hline Variabel & $\mathbf{N}$ & $\boldsymbol{x}_{\text {hitung }}^{2}$ & $\boldsymbol{x}_{\text {tabel }}^{\mathbf{2}}$ & Ket. \\
\hline $\begin{array}{c}\text { Kecerdasan } \\
\text { Emosional }\end{array}$ & 70 & $-104,7753$ & 9,49 & Normal \\
$\begin{array}{c}\text { Kemandirian } \\
\text { Belajar }\end{array}$ & 70 & $-85,3437$ & 9,49 & Normal \\
$\begin{array}{c}\text { Kemampuan } \\
\text { berpikir kreatif }\end{array}$ & 70 & $-199,0052$ & 9,49 & Normal \\
\hline
\end{tabular}

Berdasarkan hasil uji normalitas pada tabel di atas variabel kecerdasan emosional terdapat $x_{\text {hitung }}^{2}<x_{\text {tabel }}^{2}$ yaitu $-104,7753<9,49$ maka berdistribusi normal. Dan variabel kemandirian belajar terdapat $\quad x_{\text {hitung }}^{2}<x_{\text {tabel }}^{2} \quad$ yaitu $-85,3437<9,49$ maka berdistribusi normal. Dan Dan variabel kemampuan berpikir kreatif terdapat $x_{\text {hitung }}^{2}<x_{\text {tabel }}^{2}$ yaitu $\quad-199,0052<9,49 \quad$ maka berdistribusi normal.

Tabel 5. Uji Homogenitas Tes Kemampuan Berpikir Kreatif
Jurnal Pendidikan Matematika

Volume 4 Nomor 1 Tahun 2020

\begin{tabular}{ccccccc}
\hline Kelas & $\begin{array}{c}\mathbf{d b}(\mathbf{n} \mathbf{1} / \mathbf{d b} \\
\mathbf{- 1})\end{array}$ & $\mathbf{S t}^{2}$ & $\mathbf{d b ~ S t}^{2}$ & $\mathbf{l o g} \mathbf{S t}^{2}$ & $\begin{array}{c}\mathbf{d b} \mathbf{l o g} \\
\mathbf{S t}^{2}\end{array}$ \\
\hline VIII A & 35 & 0,03 & 9,63 & 337,2 & 0,98 & 34,4 \\
VIII E & 35 & 0,03 & 6,87 & 240,5 & 0,84 & 29,3 \\
VIII F & 35 & 0,03 & 63,49 & 2222,2 & 1,80 & 63,1 \\
& 105 & & & & & 126,8 \\
\hline
\end{tabular}

Berdasarkan hasil uji homogenitas pada table di atas diperoleh nilai $x_{\text {hitung }}^{2}=5,27$. Pada taraf nyata $a=0,05$, maka di dapat $x_{\text {tabel }}^{2}=5,99$. Karena $x_{\text {hitung }}^{2}<x_{\text {tabel }}^{2}$, maka dapat disimpulkan bahwa data hasil tes kemampuan berpikir kreatif siswa mempunyai varians yang homogen.

Tabel 6. Uji Linieritas Regresi Linier Sederhana

\begin{tabular}{|c|c|c|c|c|}
\hline Variabel & $\begin{array}{c}\text { Model } \\
\text { Regresi }\end{array}$ & $\mathbf{F}_{\text {hitung }}$ & $\mathbf{F}_{\text {tabel }}$ & $\begin{array}{c}\text { Kriteri } \\
\mathbf{a}\end{array}$ \\
\hline $\begin{array}{c}\text { Kecerdasan } \\
\text { emosional }\end{array}$ & $\begin{array}{l}Y=72,65 \\
+0,13 X\end{array}$ & & 1,76 & Linier \\
\hline $\begin{array}{c}\text { Kemandirian } \\
\text { belajar }\end{array}$ & $\begin{array}{l}Y=99,30 \\
-0,20 X\end{array}$ & 22201 &, 79 & Linier \\
\hline
\end{tabular}

Berdasarkan tabel di atas bahwa uji kelinieran kecerdasan emosional terdapat $F_{\text {hitung }}<F_{\text {tabel }} \quad$ yaitu $\quad-1,83334<$ 1,76 maka model regresi liniear sederhana diterima. Sedangkan uji kelinieran kemandirian belajar terdapat $F_{\text {hitung }}<$ $F_{\text {tabel }}$ yaitu $-2,2381<1,79$ maka model regresi liniear sederhana diterima.

Berdasarkan hasil analisis pengujian hipotesis dari angket kecerdasan emosional diperoleh persamaan regresi yaitu $Y=$ $72,65+0,13 X$. Nilai rata-rata kecerdasan emosional $\left(X_{1}\right)$ adalah 95,95. Jika niali rata-rata kecerdasan emosional dimasukkan dalam persamaan regresi menjadi $\quad Y=72,65+0,13(95,95)=$ $72,65+12,4735$ artinya nilai rata-rata kecerdasan emosional sebesar 72,65 poin akan meningkatkan nilai kemampuan berpikir kreatif sebesar 12,4835 poin. Dan sebaliknya jika nilai kecerdasan emosional turun sebesar 72,65 poin maka nilai dari kemampuan berpikir kreatif juga mengalami penurunan sebesar 12,4735 poin. Tetapi ketika terlihat pada korelasi atau nilai $\mathrm{R}=0,07$, menujukkan derajat hubungan yang lemah, yang berarti bahwa antara variabel kecerdasan emosional dan 


\section{$\pi$ (Phi)}

kemampuan berpikir kreatif memang terdapat korelasi, akan tetapi korelasi itu lemah.

Berdasarkan hasil analisis pengujian hipotesis dari angket kemandirian belajar diperoleh persamaan regresi yaitu $Y=$ $99,30-0,20 X$. Nilai rata-rata kemandirian belajar $\left(\mathrm{X}_{2}\right)$ adalah 63,98. Jika niali rata-rata kemandirian belajar dimasukkan dalam persamaan regresi menjadi $\quad Y=99,30-0,20(63,98)=$ $99,30-12,796$ artinya nilai rata-rata kemandirian belajar sebesar 86,504 poin akan meningkatkan nilai kemampuan berpikir kreatif sebesar 12,796 poin. Dan sebaliknya jika nilai kemandirian belajar turun sebesar 86,504 poin maka nilai dari kemampuan berpikir kreatif juga mengalami penurunan sebesar 12,796 poin. Tetapi ketika terlihat pada korelasi atau nilai $\mathrm{R}=-0,08$, menujukkan derajat hubungan yang tidak ada, yang berarti bahwa antara variabel kemandirian belajar dan kemampuan berpikir kreatif memang terdapat korelasi, akan tetapi korelasi itu tidak ada.

Berdasarkan hasil analisis pada koefisien korelasi regresi ganda untuk kecerdasan emosional $\mathrm{X}_{1}=0,309$ lebih besar daripada koefisien regresi untuk kemandiirian belajar $X_{2}=-0,424$. Jadi, bila nilai rata-rata masing-masing variabel bebas dimasukkan, maka kemampuan berpikir kreatif $Y=83,430+$ $0,309(95,95)-0,424(63,98)=85,95$.

Maka diperkirakan kemampuan berpikir kreatif siswa adalah 85,95. Tetapi ketika terlihat pada korelasi atau nilai $\mathrm{r}=0,15$, menujukkan derajat hubungan yang sedang yang berarti bahwa antara variabel kecerdasan emosional dan kemandirian belajar terhadap kemampuan berpikir kreatif terdapat korelasi yang lemah. Hal ini disebabkan bahwa siswa dalam menunjang proses pembelajaran perlu memiliki kemandirian belajar yang tinggi karena tidak semua siswa memiliki kemandirian belajar yang tinggi, terkadang dalam satu kelas kemandirian belajar yang dimliki berbeda-beda. Sedangkan koefisien determinasinya adalah $2,8 \%$, ini berarti bahwa variabel kemampuan berpikir kreatif siswa dipengaruhi sebanyak 2,8\% oleh variabel kecerdasan emosional dan kemandirian belajar, sedangkan sisanya 97,2\% dipengaruhi oleh faktor lainnya tidak diteliti dalam penelitan ini. Juga berdasarkan Uji $F$ diperoleh $F_{\text {hitung }}=5,35$ sedangkan $F_{\text {tabel }}=3,09$. Ternyata $F_{\text {hitung }}$ lebih besar dari $F_{\text {tabel }}(5,35>3,09)$, maka koefisien korelasi ganda yang ditemukan adalah signifikan (dapat diberlakukan untuk populasi dimana sampel diambil).

\section{SIMPULAN DAN SARAN}

Berdasarkan hasil penelitian dan pembahasan yang telah dilakukan dapat disimpulkan sebagai berikut:

1. Terdapat pengaruh antara kecerdasan emosional terhadap berpikir kreatif siswa. Dapat ditunjukkan dengan $\mathrm{r}=$ 0,07 yang berarti keeratan hubungan antara kecerdasan emosional dan berpikir kreatif termasuk dalam kategori lemah.

2. Tidak terdapat pengaruh antara kemandirian belajar terhadap berpikir kreatif siswa. Dapat ditunjukkan dengan $r=-0,08$ yang berarti keeratan hubungan antara kemandirian belajar dan berpikir kreatif termasuk dalam kategori sangat lemah.

3. Terdapat pengaruh antara kecerdasan emosional dan kemandirian belajar terhadap berpikir kreatif siswa. Dapat ditunjukkan dengan $r=0,15$ yang berarti keeratan hubungan antara kecerdasan emosional dan kemandirian belajar terhadap berpikir kreatif termasuk dalam kategori rendah.

\section{DAFTAR PUSTAKA}

Danim S. Dan Khairil. (2010). Psikologi Pendidikan. Bandung : Alfabeta. 
Iskandar. (2009). Psikologi Pendidikan Sebuah Orientasi Baru. Perpustakaan Nasional RI.

Lestari, Karunia Eka, dan Yudhanegara, Mokhammad Ridwan. (2015). Penelitian Pendidikan Matematika Panduan Praktis Menyusun Skripsi, Tesis, danLaporan Penelitian dengan Pendekatan Kuantitatif, Kualitatif, dan Kombinasi Disertai dengan Model Pembelajaran dan Kemampuan Matematis. Karawang : Refika Aditama.

Mujiman Haris. (2007). Manajemen Pelatihan Berbasis Belajar Mandiri. Yogyakarta : Pustaka belajar.

Sugiyono. (2018). Metode Penelitian Pendidikan Pendekatan Kuantitatif Kualitatif dan R\&D. Bandung : Alfabeta.

Uno Hamzah B. (2010). Orientasi Baru Dalam Psikologi Pembelajaran. Jakarta : PT. Bumi Aksara. 